\title{
The identity trajectories of older academics
}

\section{Workplace affordances and individual subjectivities}

\section{Gosia Iwaniec-Thompson}

\section{I8. I Introduction}

With the rapid development of new knowledge, open digital networked technologies, and ever-evolving teaching methods and research trends in the Higher Education (HE) sector, older academics are as likely as other academics to continue developing their expertise and practice. Future projections of an ageing society and recent trends in delayed retirement indicate a growing number of older academics. Yet, empirical research considering older academics' identity development is scarce and thus, there is a need to examine the changing landscape of academic practice by focusing on older academics' identity development. Older academics are understood as 50 years old and over as aligned with the wider literature (Larkin \& Neumann, 2009; ONS, 2006).

Academic identity in Chapter 18 is studied from a sociocultural perspective, whereby understanding changes in academic identity focus on participation in practice (Wenger, 1998; Wenger-Trayner et al., 2014). Academics have multiple sub-identities emerging through an engagement within a landscape of practice (McLean, 2012). Wenger's term "landscape of practice" is adopted here to refer to different communities of practice (CoP) of academics involving disciplinary, institutional and HE contexts that constitute academic sub-identities, for instance, a teacher, a researcher, a leader, or a manager. This research brings a unique perspective on academic's identity development by extending Lave and Wenger's work on identification by adding a dimension of identity development which involves an understanding of subjective interpretation of practice (Billett, 2004). In consequence, Chapter 18 explores tensions between different sub-identities, and affordances (enablers and constraints) of older academics' identity development in the changing landscape of their practice.

\subsection{Ageing academics}

HE institutions are positioned at the forefront of an ageing workforce boom due to trends in an ageing society, the lifting of retirement age, and thus prolonged retirement. Kaskie (2017) suggested that the HE academic sector employs a greater proportion of workers over 65 relative to the general labour force, thus 
surpassing all other sectors. In fact, the annual UK Universities report (Universities UK \& Higher Education Statistics Agency, 2014) compared statistics from 2006 to 2016 and found a general increase in numbers across all ages in full time academic roles $(39.9 \%$ increase in the 31-35 year old age group, 36-40-year-olds accounting for a further $17.2 \%$, and around 35\% 51-55-years old). However, the proportion of part-time academic staff (aged 61-65 years old) increased by $44.1 \%$, while those in the 66 and over age group rose by a staggering $148.5 \%$ over ten years. Thus, by 2016, more ageing academics were remaining in part-time employment. Figure 18.1 illustrates these changes for full time and part-time employment of academic staff.

\section{8.2. I Delayed retirement}

In tandem with a growing number of ageing academics, empirical research suggests that older academics' transition to retirement is and will be increasingly extended (Cahill et al., 2018; Kaskie, 2017). Currently, in the UK, the State Pension Age is 66. At the same time, studies show that many countries abolished a mandatory age of retirement (Unwin et al., 2015). The UK introduced such policies in 2006 under the Equality Act, which makes it illegal for employers to require retirement to employees who are at the retirement age. Furthermore, there are several studies exploring motivational and other factors leading academics to delay their retirement. For instance, Cahill et al. (2018) concluded that amongst many predictive factors to remain in employment and delay retirement, the two most important reasons were financial necessity and job satisfaction. Dorfman (2009) found that professors remained employed as they enjoyed research, whilst Winston and Barnes (2007) concluded that academics work beyond retirement as they are often free of the responsibilities they dislike, for instance, teaching and administration or management and research (Williamson, Cook, Salmeron, \& Burton, 2010). Also, Cahil et al. (2018) highlighted that many academics fear losing contact with their students and their colleagues, so they choose to stay in employment for as long as they can. The factor of flexibility related to working practice, working hours, and more opportunities of part-time work, was also identified by Koopman-Boyden and Macdonald (2003). They proposed that the very nature of academic work allows older academics to continue to undertake project-based work or consultancy, while moving into full retirement.

\section{8.2.2 Identity tensions}

Given the growing trend of ageing academics, there is a need to focus research on older academics. However, as the literature on older academics is limited, Chapter 18 drew on the broader literature about all academic age ranges when considering the changing nature of their practice in a dynamic HE sector, impacting their identity development. Contemporary research indicates that rapid changes in the UK HE sector and the dynamic nature of academic practice affect academic identity. 

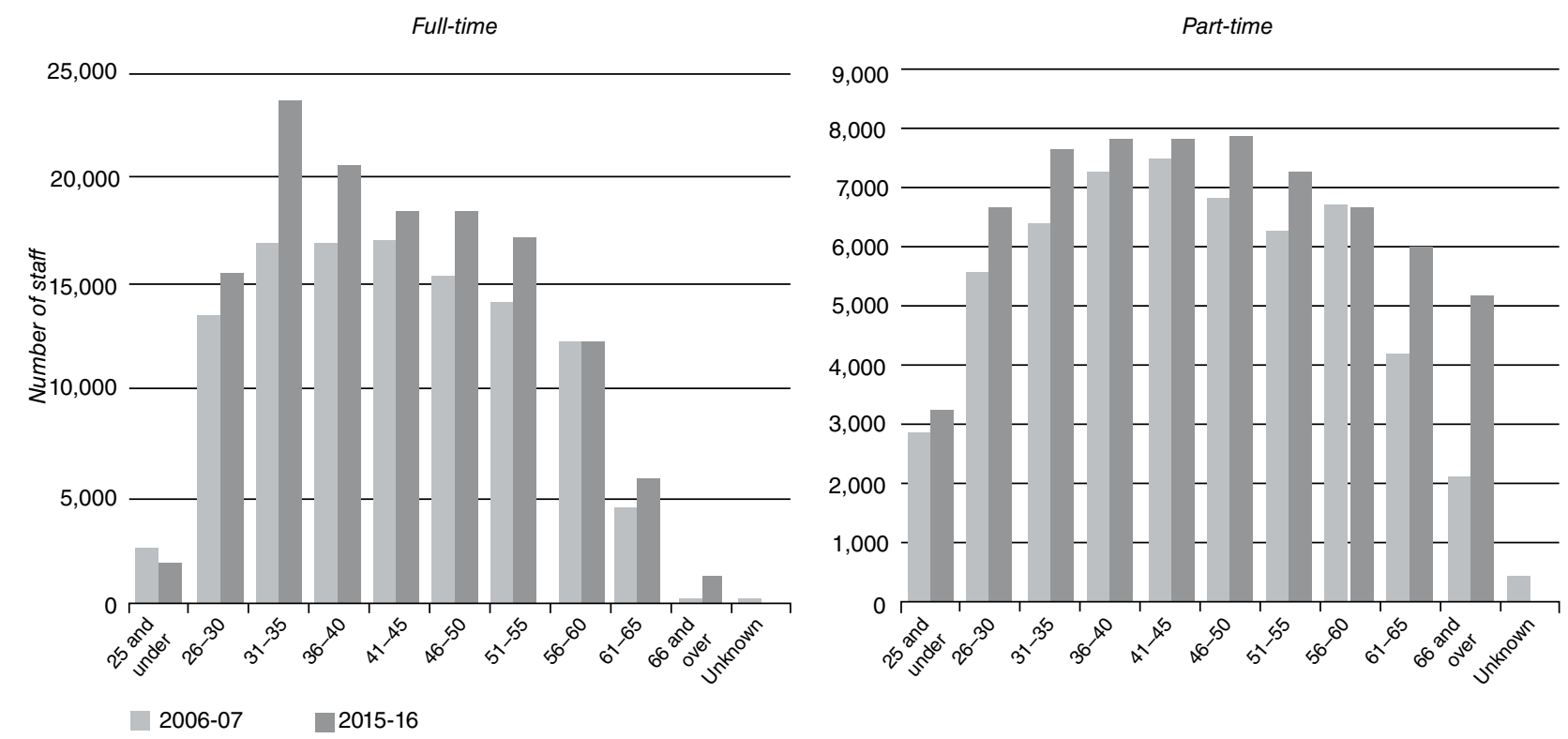

Figure 18.I Change in age profile of full-time and part-time academic staff in UK universities between 2006-2007 and 20I5-20I6. 
For example, a case study of two mid-career academics in a Cypriot university, discussed increased managerialism, marketisation and massification leading academics to negotiate the boundaries of their practice and the cost associated with their lateral moves (James \& Lokhtina, 2018). Findings illustrated the unequal power relationships in the culture of academic practice that had an impact on academic identity and engagement in practice. Also, academics' practice and identities were often in constant tension, because of the struggles they encountered in their engagement with dynamic practice and the difficult relationships between colleagues. Furthermore, a phenomenological study of identity work that academics engaged in as they adopted web-based tools (Bennett, 2017). The study argued that some academics experienced feelings of anxiety and vulnerability as they made changes to their practices. These changes required undertaking identity work to manage increased exposure through social media and negotiate the risk of failure associated with trying something new. This study illustrated academics were primarily motivated to be a "good teacher" rather than responding to top down pressures to bring about change and overcome these feelings. These above studies highlight the changing landscape of the HE sector combined with dynamic academic practice that impacts evolving academic identity.

\section{8.3 Introducing study design}

The literature and initial reflections reported in Chapter 18 is part of a broader $\mathrm{PhD}$ thesis. The epistemological positioning of this study is one of constructivism. Constructivism seek understanding of the world in which individuals live, work and where knowledge is constructed by individuals in interaction with others, in consequence the ontological rejection of the notion of an objective external reality independent of people (Creswell, 2014). To that end, this study investigated academics' learning and identity, using an ethnographic approach. The experiences of eleven academics at the OU were investigated. The purposive sampling included academics aged 50- to 70-year-old, including six males and five females. The data were collected over a six-month period. Each participant was interviewed three times over the course of three months either face to face or via Skype. In between the interviews, participants were observed on at least two occasions as they went about their work (for instance, during various meetings, during their desk work, online meetings).

The goal of this research was for the researcher to report different perspectives as themes develop in the findings by relying on quotes as evidence and observation notes from the field. In consequence, this epistemological framing had a particular affinity with constructivism or interpretivist (Creswell, 2014). The focus on lived experiences and social behaviours of an identifiable group of people studied in their natural context to develop an overall cultural interpretation is defined as an ethnographic approach (Creswell, 2014). In making sense of how academics engage with those changes in their practice, the next step therefore is to explore the nature of academic identity. 


\section{8.4 Towards the conceptualisation of academic identity}

The term "identity" is a contested term due to various epistemological traditions that can inform the conceptualisation of the term. For instance, identity can be understood as one's identification with a landscape of practice where an individual constitutes their identity through belonging to varied communities (Kreber, 2010). In contrast, identity can also be understood as a self-concept, a view which links identity to humanist notions of individuation, self-actualisation and gaining greater self-awareness of who they are (Hyland \& Tse, 2012). Studies of academic identity recognise both individual and broader structural aspects of identity (Clegg, 2008; Henkel, 2005). Henkel (2000, p. 251) viewed academic identity as both distinctively "individual and embedded in the communities of primary importance to them", whereas Clegg (2008, p. 329) argued that identity is a

multiple and shifting term [which] exists alongside other aspects of how people understand their personhood and ways of being in the world, is not a fixed property, but part of the lived complexity of a person's project and their ways of being in those sites which are constituted as being part of the academic.

Both examples, without being explicit, refer to the notion of practice as a way of contextualising an individual in the world. Thus, both authors suggested that academic identity is constructed and negotiated in social interaction in the everyday landscape of practices. To explore the identities of academics, there is a need to examine their landscape of practice, which impacts the development and renegotiation of their identities. To this end, the conceptualisation of identity used in Chapter 18 is positioned within a sociocultural and situated perspective that recognises identity as a relational phenomenon, mediated, developed and re-negotiated through practice in cultural and social settings (Lankveld et al., 2017; van Winkel et al., 2018; Wenger-Trayner et al., 2014).

\section{8.5 Studies on academic identity through the CoP lens}

Several studies have explored situated and sociocultural perspectives, and in particular, used the CoP framework in understanding academics' identity. For example, Swennen et al. (2010, p. 131) considered university teacher educators' identity as "socially constructed self", developed in participation with others in the landscape of practice. Whereas, Warhurst (2008) examined novice academics by emphasising that learning is a process of identity formation or re-formation in relation to the community sustaining particular forms of practice. Furthermore, Cahill et al. (2018) have argued for participation within a CoP as a "source of identity" within academic context.

Only one study was found considering older academics' identity formation, who experience transitions across the landscape of practice and changing forms of academic membership, drawing on Wenger's concept of CoP. Namely, James (2007) explored the tensions between academics different identities, and trajectories of 
identification, that constitute the participation of academics in a landscape of practice. James (2007) argued that academics roles, as old-timers within CoP, may be shaped by institutional and societal contexts over which they have little or no control. Therefore, in line with studies using CoP framework, the orientation in Chapter 18 and the study context also considers academics' learning whereby engaging in social practice and negotiating meaning in the landscape of practice brings about changes in an individual's identity (Lave \& Wenger, 1991).

\subsection{Participation and reification in the landscape of practice}

In order to apply the lens of $\mathrm{CoP}$ to older academic's practice, there is a need to discuss its main assumptions to understand the link between identity development and practice. Wenger (1998, p. 15) defined practice as "the body of knowledge, methods, tools, stories, cases, documents, which members share and develop together". He described a $\mathrm{CoP}$ as having the properties of mutual engagement, joint enterprise, and shared repertoire. Wenger (1998) contended that individuals' engagement in a $\mathrm{CoP}$ entails a process of negotiation of meaning which takes place in the convergence of two processes. Individuals move through both participation and reification on a trajectory from newcomers to a full participant through Legitimate Peripheral Participation (LPP).

Participation in a CoP considers acting and interacting in the community of others engaged in the same area of practice. The participation is both personal and social and based on mutuality, but not necessarily equal involvement. Participation involves academics engaging directly in activities, conversations, reflections, and other forms of personal participation in academic practice. For example, academics teaching or working collaboratively on a research project as noted in my study.

Reification, on the other hand, encompasses both a process and its resulting form. Reification involves academics producing artefacts (such as tools, words, symbols, rules, documents, concepts, theories, and so on) around which the negotiation of meaning is organised. For example, academics producing course contents, a policy document, or a theory in their discipline as found in the study. Participation and reification are complementary processes which are situated in practice.

\subsubsection{Identity and practice}

Wenger (1998) described a profound parallel between identity and practice. The formation of a CoP does not only involve the negotiation of meanings, but also, and of equal importance, the negotiation of identities. Indeed, each of the key concepts critical to negotiation of meaning in practice has parallel concepts in negotiations of identity; community as membership, shared histories of learning as learning trajectories, boundary and landscape as nexus of multimembership, negotiation of meaning (in terms of participation and reification) as negotiated experience of self (in terms of participation and reification) (Wenger, 1999, p. 150). 
A full CoP participant does not mean an older participant, but one that have developed expertise in the community. Full participation within a CoP is desirable as it provides access to certain knowledge, ways of knowing, and modes of conduct, which are inherent in the practice of a full participant (Wenger, 1999). Thus, participants wanting to achieve centripetal movement within the community negotiate participation and make sense of both the practice and their position in it.

\section{8.5.3 Multiple identities of older academics}

The practice of academics is ever changing and socially legitimated, where academics interpret themselves as a certain individual within a certain context (Winter, 2009). Academics' participation in various practices results in multiple identities. Traditionally, universities have been institutions of both learning and scholarly inquiry. Thus, in general academics would engage with teaching and research. More recently, academics also engage in management, administration, and leadership responsibilities (Winter, 2009). A study by Deem and Johnson (2001) highlighted that some academics manage to retain a balanced teaching and research portfolio, whilst others focus on one aspect of practice or the other. Furthermore, other studies showed that academics become full-time manager academics or take on leadership responsibilities, and thus have little or no time for teaching and research (Boyd \& Smith, 2016). Both findings were confirmed in this study, whereby some academics' identity development focused on research, teaching, or leadership or a combination of both or even all three areas of practice, for instance, research and leadership. Moreover, initial findings in this study consisted of academics' identities including a teacher, researcher, scholar, leader, manager, cross disciplinary brokerer, consultant, discipline expert.

\section{8.5.4 The dynamic nature of identity development in a landscape of practice}

Along with my study initial findings, the literature (Lankveld et al., 2017) indicates that institutional factors, such as introducing new initiatives, goals, directions, and policies at their institution, may especially influence academics' administration, managerial, or leadership responsibilities and hence practices. In fact, the latter is prevalent amongst older academics who often take on management and leadership roles based on their long experience in academia. These roles are often temporary. McAlpine (2012) concluded that academics conceptualise themselves as having multiple identities due to the changing forms of academic community membership. Thus, they can become leaders and managers alongside their teaching identity. Furthermore, the boundaries of HE are increasingly "porous" and academics are developing a wider ranges of identities influenced by activity beyond the university (Clegg, 2008), such as international projects, cross-disciplinary research or governmental and private professional bodies and employers (Martin, Lord, \& WarrenSmith, 2020). This leads academics to be involved in the landscape of CoP which extend beyond their immediate CoP. 
Development of all these identities at the same time may not always be possible, and some may be more pronounced than others, or they may clash altogether. Winter (2009) suggested contradictions and conflicts that arise from these competing identities as academics enact their multifaceted practice. This leads academics to experience competing priorities in their identities (Bolden, Petrov, \& Gosling, 2009). Furthermore, some authors have argued that academics most strongly identify with their discipline rather than their workplace (cf. Henkel, 2005) as confirmed in the findings of this study. For example, one academic in particular talked about his disciplinary work outside of his workplace with a great passion. Indeed, practices change and evolve over time and over contexts and new challenges require new ways of practising which affect identities of the academics.

\section{8.5.5 Modes of identification}

By participating in the landscape of practice academics engage in learning activities that imply changes in individuals' identities (Lave \& Wenger, 1991). Wenger emphasized that these changes involve engagement, imagination and aligning one's skills, knowledge and identity with the community, thus learning arises out of engagement in the practice of the CoP rather than merely engaging in educational activity (Lave \& Wenger, 1991). Wenger suggests three modes of identification that positions an individual in the landscape of CoP: engagement, imagination, and alignment.

\subsubsection{Engagement}

Engagement, being the most immediate relation to practice, involves engaging in work activities, working collaboratively or alone. Engagement provides direct experience of what the community is all about, whether this experience is one of competence or incompetence and whether participants develop an identity of participation or non-participation. For example, the findings indicated that some academics focused their engagement on the development of their research identities, but disengaged with leadership or teaching practices, and indicated no desire to get competence in these practices. Conversely, other academics practice focused on developing leadership identities which left limited time for research.

\subsubsection{Alignment}

Alignment involves a two-way process of coordinating perspectives, interpretations, actions, and contexts of a participant's trajectory into the CoP. For example, a teaching academic aligned some of their teaching methods to those practised in their department but also introduced innovation by suggesting using Twitter in their course, which changed aspects of the teaching culture of the department. Alignment becomes very deep aspects of participant's identities as it concerns power which can amplify but also disempowers sense of what is possible. For example, in my study one academic struggled to establish his area of work as "proper". 


\subsubsection{Imagination}

Imagination involves an understanding of how we belong or not to a CoP, it is extrapolating our own experiences through time and space. For example, the study found that research-engaged academics imagine belonging to a wide disciplinary community even though they may be the only ones doing research in a certain area of their workplace. Indeed, the study findings showed that all participants expressed ongoing interests in research and scholarship practice and its value in their disciplines and workplace. Yet, some participants admitted having no time to engage in the activity itself. This finding has implications for participants' identity. Namely, participants recognise the importance of research in the identity of an academic and may even align their identity to the place of research even if they do not engage in primary research themselves.

\section{8.6 Subjectivity in identity development}

Thus far, Chapter 18 has argued that the development of academics' multiple identities is both social and CoPs dependent. However, researchers urge that both the context and the way that individuals make sense of this context should be examined when investigating professional identity. It is at this point, where Wenger's work has been critiqued, as he provides limited attention to individual subjectivities to understand the choices individual's make in participation in practice (Fuller et al., 2005).

Each academic's experience will be unique due to "the inevitable negotiation between the workplace's norms and practices and the individuals' subjectivities and identities" (Billett 2004, p. 114). Individuals enter workplaces with their own idiosyncratic personal learning experiences, perceptions and memories which will shape their dispositions to particular participatory practices For this reason, research focusing on academic identity should consider the subjectivities that individuals employ within their academic landscape of practice. Therefore, the processes of alignment (congruence and incongruence) with the values, practice and norms of the community and also individuals' biographies, norms and values are seen as integral to their academic identity formation. This duality is conceptualised by Billet's (2004) notion of co-participation, and describes how access to identity development is afforded, on the one hand, and how workers elect to engage with what is afforded to them which shapes their identity, on the other. Each individual's understanding is a subjective reconstruction or construal of practice that shapes one's identity (Hodkinson et al., 2008).

\subsection{Affordances for identity development}

By focusing on the situated nature of practice, Eraut (2009) pointed out that the different local goals, norms and role boundaries of workplaces create varied affordances to engage in participatory opportunities. Research suggests that the myriad forms of academic identities are constituted by multifaceted contexts. These are: the academic's workplace environment, the wider context of national 
and international HE, their discipline context, as well as social interaction with peers and students. These contexts can play an important role in either strengthening or inhibiting the development of academic identity. Furthermore, each of these contexts can have a varying impact on academic identity (Lankveld et al., 2017). Furthermore, these contexts can be understood as learning affordances (Billett, 2004) which can constrain or resource the identity development. These highlight potential, disempowering, or exclusionary experiences in which affordances may not be evenly available.

\subsection{Affordances enhancing identity development}

One of the affordances that has been mentioned by several studies that align with the findings of Chapter 18 was a collegial and supportive environment in the academics workplace and across discipline networks (Martin et al., 2020). Feeling supported and respected by their colleagues meant for academics that they flourished and developed their identities by giving each other emotional and practical support (Lankveld et al., 2017). Furthermore, the study found being a recognised expert in a discipline afforded identity development by being invited to conferences or being approached by colleagues to participate in collaboration, thus developing expertise identity in respective discipline. The participants' strong identification with research and scholarship translated into the focus on intensive applied research that stressed collaboration and practical implications of their research across disciplines. The expressions of commitment, pride, and passion were evident in academics' accounts, reinforcing their identity as researchers and scholars.

The participants in this study also interpreted their past experiences as an affordance for identity development, for example, their teaching experience. Through reflecting on these experiences, they were able to develop themselves as professionals. These findings align with the conceptualisation of identity as negotiated in everyday interaction and experience (Archer, 2008).

\subsubsection{Affordances restricting identity development}

In contrast, other studies reported that the work environment had a constraining impact on identity when academics perceived their departments to be competitive, hierarchical, lacking in trust, or valuing research more than teaching. In such environments, academics felt isolated and inhibited to ask for help and support to develop either their teaching or research identities (Cahill et al., 2018). An example from this study's findings showed that some academics felt that their career progression was restricted, as well as having limited formal developmental opportunities.

The findings of this study also indicate that although the diverse prior experience in participants' practice meant that they could be involved in different practices, it also created some tensions. Thus, some of academics' identities were an obstacle for the development of other academic identities. Indeed, several academics discussed struggles with keeping up with research practice due to management and 
leadership responsibilities and the specific nature of their discipline. These findings are aligned with other studies mentioned by Bolden et al. (2009).

\subsubsection{Identity development in Open World Learning}

With the rapid development of open world learning technologies older academics continue developing identities. However, the challenge of encouraging older academics in HE to adopt to these changes is frequently noted within the academic development community. The initial findings of this study noted two aspects of using social media. On the one hand, the study that the benefits of utilizing social networking when carrying out research were clearly recognised by many participants. Consistent results across studies have revealed that social media sites provided a convenient environment for scholarly communication and research dissemination. These findings aligned with other studies (Bennett, 2017; Kara et al., 2020). Furthermore, the findings reported that academics used ResearchGate and Academia.edu for keeping themselves up to date in their field, promoting their work online, and maintaining their professional image.

On the other hand, there were some barriers hindering the adoption of social media. The challenge of encouraging academics in HE to adopt social media to support their teaching, research, and management roles was frequently noted within the academic development community (Brown, 2013), especially amongst older academics (Gelade, 2013). For example, studies considering identity development uncertainties in adopting social media in teaching and research practice (Bennett, 2017; Kara et al., 2020). Indeed, Greenhow and Gleason (2014) found that age played an important role in the decision to adopt social media for teaching. The findings of this study aligned with Bennet's study (2017) whereby some academics discussed uncertainties related to the use of social media, yet these were alleviated by time they spent on getting used to new practice for the benefit of their research and teaching.

\section{8.8 Discussion and moving forwards}

The aim of Chapter 18 was to problematise the dynamic nature of older academics' identities and report some initial findings. The scarce literature on older academics necessitated drawing on wider literature. This calls for more research focusing on older academics given delayed retirement and the increased ageing academic population. The conclusions of James's (2007) study compared to the findings of this study revealed that an individual subjectivity (Billett, 2004) in understanding older academics identity development was not addressed. Thus, this study builds on previous work by adding an additional framework in order to understand identity development of older academics.

Chapter 18 indicated that older academic identity consists of sub-identities across a landscape of practice, including but not limited to: teacher, researcher, leader, consultant, discipline experts. The findings indicated that the academics were recognised for their expertise and thus seen as sources of knowledge. However, 
multiplicity of academic identities means their practice is contested, hence future research should address the ways how those tensions could be addressed. Participating in the landscape of practice, academics involve dynamic context of HE sector and evolving workplaces including technological changes. The chapter indicated that both affordances (enablers and obstacles) of the practice but also individual subjectivities shape academics identities development. More research is necessary to understand how workplaces could use these insights to foster an environment where particularly the barriers are addressed. For example, the use of open access and social media use was discussed, both as an affordance that helped academics to promote their work, but also as an uncertainty that has implications for more focused help for individual academics' development.

\subsection{Implications for practice}

The practical implications of distinguishing multiple identities of older academics' could enhance an individual's understanding for thinking about their own professional development. There are several tensions caused by the dynamic and multiple identities of older academics. This could both inform practice, concerning, for example, emotional processes involved in these changes, but also encourage younger and older academics to negotiate time to maintain the identities that were pushed on the periphery for maintaining an appropriate balance.

\section{References}

Archer, L. (2008) Younger academics' constructions of "authenticity" "success" and professional identity. Studies in Higher Education, 33(4), 385-403. doi:10.1080/03075070802211729.

Bennett, L. (2017) Social media, academics' identity work and the good teacher. International Journal for Academic Development, 22(3), 245-256. doi:10.1080/1360144X.2017.1305961.

Billett, S. (2004) Co-participation at work: learning through work and throughout working lives. Studies in the Education of Adults, 36(2), 190-205. doi:10.1080/02660830.2004 .11661496 .

Bolden, R., Petrov, G., \& Gosling, J. (2009) Distributed leadership in higher education: rhetoric and reality. Educational Management Administration and Leadership, 37(2), 257-277. doi:10.1177/1741143208100301.

Boyd, P., \& Smith, C. (2016) The contemporary academic: orientation towards research work and researcher identity of higher education lecturers in the health professions. Studies in Higher Education, 41(4), 678-695. doi:10.1080/03075079.2014.943657.

Brown, S. (2013) Large-scale innovation and change in UK higher education. Research in Learning Technology, 21(1063519), 1-13. doi:10.3402/rlt.v21i0.22316.

Cahill, M. et al. (2018) The transition to retirement experiences of academics in "higher education": a meta-ethnography. The Gerontologist, 1-19. doi:10.1093/geront/gnx206.

Clegg, S. (2008) Academic identities under threat? 34(3), 329-345. doi:10.1080/014 11920701532269.

Creswell, J. (2014) Qualitative inquiry E research design choosing among five approaches (3rd ed.). London: SAGE Publications LTD.

Deem, R., \& Johnson, R. (2001) Learning to be a manager-academic in UK universities: coping with risks and uncertainties. In Cultures of Learning: Risk, Uncertainty and Learning Conference, Bristol, 19-22 April. 
Dorfman, L.T. (2009) Ten years later: a follow-up study of professors still working after age 70. Educational Gerontology, 35(11), 1032-1045. doi:10.1080/03601270903212294.

Eraut, M. (2009) How professionals learn through work. In Learning to be professional through a higher education (pp. 1-29). Available at: http://www.google.fr/search?q=\%22The+natu re + of + immersive + experience $\% 22 \& b \operatorname{tnG}=$ Rechercher $\& h l=$ fr $\&$ client $=$ firefox a\&rls $=$ org.mozilla:fr:official\&sa $=2$.

Fuller, A. et al. (2005) Learning as peripheral participation in communities of practice: a reassessment of key concepts in workplace learning. British Educational Research Journal, 31(1), 49-68. doi:10.1080/0141192052000310029.

Gelade, S. (2013) Workplace learning in academia: (Older) bones of contention? Journal of Organisational Transformation \& Social Change, 4(3), 213-224. doi:10.1386/jots.4.3.213.

Greenhow, C., \& Gleason, B. (2014) Social scholarship: reconsidering scholarly practices in the age of social media. British Journal of Educational Technology, 45(3), 392-402. doi: https://doi.org/10.1111/bjet.12150.

Henkel, M. (2000) Academic identities and policy change in higher education. London: Jessica Kingsley.

Henkel, M. (2005) Academic identity and autonomy in a changing policy environment. Knowledge Creation Diffusion Utilization, 49(1), 155-176.

Hodkinson, P., Biesta, G., \& James, D. (2008) Understanding learning culturally: overcoming the dualism between social and individual views of learning. Vocations and Learning, 1(1), 27-47. doi:10.1007/s12186-007-9001-y.

Hyland, K., \& Tse, P. (2012) "She has received many honours": identity construction in article bio statements. Journal of English for Academic Purposes, 11(2), 155-165. doi:10.1016/j. jeap.2012.01.001.

James, N. (2007) The learning trajectories of 'old-timers': academic identities and communities of practice in higher education. In Communities of practice (pp. 131-144). New York: Routledge.

James, N., \& Lokhtina, I. (2018) Feeling on the periphery? The challenge of supporting academic development and identity through communities of practice. Studies in the Education of Adults, 50(1), 39-56. doi:10.1080/02660830.2018.1520561.

Kara, N., Çubukçuoğlu, B., \& Elçi, A. (2020) Using social media to support teaching and learning in higher education: an analysis of personal narratives. Research in Learning Technology, 28(1063519), 1-16. doi:10.25304/rlt.v28.2410.

Kaskie, B. (2017) The academy is aging in place: assessing alternatives for modifying institutions of higher education. Gerontologist, 57(5), 816-823. doi:10.1093/geront/gnw001.

Koopman-Boyden, P.G., \& Macdonald, L. (2003) Ageing, work performance and managing ageing academics. Journal of Higher Education Policy and Management, 25(1), 29-40. doi:10.1080/13600800305744.

Kreber, C. (2010) Academics' teacher identities, authenticity and pedagogy. Studies in Higher Education, 35(2), 171-194. doi:10.1080/03075070902953048.

Lankveld,T. et al. (2017) Developing a teacher identity in the university context: a systematic review of the literature. Higher Education Research and Development, 36(2), 325-342. doi:10 $.1080 / 07294360.2016 .1208154$.

Larkin,J., \& Neumann, R. (2009) Older academics and career managment: an interdisciplinary discussion. Australian Journal of Career Development, 18(3), 4-7.

Lave, J., \& Wenger, E. (1991) Situated learning: legitimate peripheral participation, learning in doing. Cambridge: Cambridge University Press. Available at: http://books.google.com/books?i $\mathrm{d}=$ CAVIOrW3vYAC\&pgis $=1$. 
Martin, L., Lord, G., \& Warren-Smith, I. (2020) Juggling hats: academic roles, identity work and new degree apprenticeships. Studies in Higher Education, 45(3), 524-537. doi:10.1080 /03075079.2018.1550478.

McAlpine, L. (2012) Shining a light on doctoral reading: implications for doctoral identities and pedagogies. Innovations in Education and Teaching International, 49(4), 351-361. doi:10. 1080/14703297.2012.728875.

McLean, N. (2012) Researching academic identity: using discursive psychology as an approach. International Journal for Academic Development, 17(2), 97-108. doi:10.1080/1360 144X.2011.599596.

ONS (2006) Projections of the UK labour force: 2006 to 2020. Office for National Statistics, 13-27.

Swennen,A., Jones, K., \& Volman, M. (2010) Teacher educators: their identities, sub-identities and implications for professional development. Professional Development in Education, 36(1-2), 131-148. doi:10.1080/19415250903457893.

Universities UK \& Higher Education Statistics Agency (2014) Patterns and trends in UK higher education 2014. London. Available at: http://www.universitiesuk.ac.uk/highereducation/Documents/2014/PatternsAndTrendsInUKHigherEducation2014.pdf.

Unwin, L. et al. (2015) Supporting an ageing workforce: implications for working life, training and skills policy in England - a literature review. Available at: http://www.llakes. ac.uk/sites/llakes.ac.uk/files/51.Nuffield report.pdf.

Warhurst, R.P. (2008) “Cigars on the flight-deck": new lecturers' participatory learning within workplace communities of practice. Studies in Higher Education, 33(4), 453-467. doi:10.1080/03075070802211828.

Wenger, E. (1998) Communities of practice: learning, meaning, and identity. Systems Thinker, 9,2-3.

Wenger, E. (1999) Communities of practice: learning, meaning, and identity. Cambridge: Cambridge University Press.

Wenger-Trayner, E., \& Wenger-Trayner, B. (2014) Learning in landscapes of practice. London: Routledge.

Wenger-Trayner, E., Fenton-O'Creevy, M., Hutchinson, S., Kubiak, C., \& Wenger-Trayner, B. (2014) Learning in landscapes of practice: boundaries, identity, and knowledgeability in practicebased learning. London: Routledge.

Williamson, M. et al. (2010) Retaining nursing faculty beyond retire- ment age. Nurse Educator, 35, 152-155.

van Winkel, M.A. et al. (2018) Identities of research-active academics in new universities: towards a complete academic profession cross-cutting different worlds of practice. Journal of Further and Higher Education, 42(4), 539-555. doi:10.1080/0309877X.2017.1301407.

Winston, N., \& Barnes, J. (2007) Anticipation of retirement among baby boomers. Journal of Women \& Aging, 19(3-4), 89-104. doi:10.1300/J074v19n03.

Winter, R. (2009) Academic manager or managed academic? Academic identity schisms in higher education. Journal of Higher Education Policy and Management, 31(2), 121-131. doi:10.1080/13600800902825835. 